\title{
KERÄSALAATIN KAASUVARASTOINTI
}

\author{
Irma SUHONEN \\ Helsingin yliopiston puutarhatieteen laitos, Viik
}

Kaasuvarastointi, jolla tässä tarkoitetaan ilman lämpötilan, happi- ja hiilidioksidipitoisuuksien säätelyyn perustuvaa varastointimenetelmää, on yleistä säilytettäessä hedelmiä eräissä maissa, kuten Englannissa, missä tämä varastointimenetelmä ensimmäisenä kehitettiin (WEst 1951, Kidd 1964, ANon. 1965). Vihannesten kaasuvarastointia tunnetaan edellistä vähemmän. Tosin jo 1930-luvulla tutkittiin varaston ilman koostumuksen, lähinnä hiilidioksidipitoisuuden, vaikutusta vihanneksien vioittumiseen (BRooks et al. 1936) tai säilymiseen (KIDD \& WEST 1932), mutta nämä tutkimukset eivät johtaneet käytännön sovellutuksiin.

Runsaat kaksikymmentä vuotta myöhemmin vihannesten varastoinnin muodostuttua muuttuneiden tuotanto- ja markkinointitapojen johdosta tärkeäksi kysymykseksi, kiinnitettiin jälleen huomiota vihannesten kaasuvarastointiin. Tutkittavina ovat olleet $\mathrm{mm}$. kaalit (Lieberman \& Hardenburg 1954, Lyons \& Rappaport 1962), tomaatti (EAves \& Lockhart 1961, Tomkins 1963), kurkku (EAKs 1956, Apeland 1961), parsa (Lipton 1965, Lougheed \& Dewey 1966) ja porkkana (Tomkins 1959, van den Berg \& Lenz 1966). Vihannesten kaasuvarastoinnista suoritettujen tutkimusten tuloksia sovelletaan käytäntöön lähinnä kuljetus- (ANON. 1966) ja markkinointipakkauksia suunniteltaessa. Varsinainen kaasuvarastointi on satunnaista (FIDLER 1963).

Edellä mainituissa tutkimuksissa varastona käytettiin tiiviitä astioita, joiden sisään johdettiin sopivaa kaasuseosta tai joissa olevan ilman koostumus muuttui astioihin sijoitettujen kasvinosien hengityksen takia. Ilman koostumuksen säätö tapahtui johtamalla jatkuvasti uutta kaasuseosta astiaan, hiilidioksidia absorboivia aineita käyttäen tai tuulettaen. Kun Helsingin yliopiston puutarhatieteen laitoksella alettiin selvittää salaatin kaasuvarastointia, päädyttiin menetelmän valinnassa yksinkertaisimpaan: kaasuvarastossa ilman koostumus muuttui salaatin hengitystoiminnan johdosta, ja ilman hiilidioksidipitoisuuden säätö suoritettiin tuulettaen. Seuraavassa selostetaan v. 1963-66 ja 1968 suoritettuja tutkimuksia. Alustavia tuloksia asiasta on esitetty jo v. 1967 (VorPIO \& HÅrdH 1967). 
Tutkimukseen tarvittava salaatti (lajikkeet Herttaässä ja Great Lakes) viljeltiin Viikissä Puutarhatieteen laitoksen koekentällä. Aikaisemmin on selostettu viljelytoimenpiteitä, sadonkorjuuta ja tuotteiden kunnostusta (VorPIo 1966). Säilytyksen ajaksi tuotteet pakattiin puulaatikoihin.

Kaasuvarastointia varten rakennettiin 12 tiivistä sinkkikaappia, jotka sijoitettiin varastoon, missä ilman lämpötila oli $1-2^{\circ}$ ja suhteellinen kosteus $90-95 \%$. Kaappien tilavuus oli 336 1. Niiden etuseinämässä oli tiiviisti suljettava oviaukko, etuseinämän kulmissa 3.5 $\mathrm{cm}$ :n läpimittaiset pyöreät aukot, jotka voitiin sulkea tulpilla. Lisäksi oli etuseinämän yläreunassa tuuletusta varten 5 pyöreää $4 \mathrm{~mm}$ :n läpimittaista reikää.

Kun varastoitava salaatti oli suljettu kaappiin, muuttui kaapissa olevan ilman koostumus kasvien hengityksen johdosta. Hiilidioksidipitoisuuden noustua tavoitemäärään aloitettiin ilman koostumuksen säätö, joka suoritettiin kaapissa olevia tuuletusreikiä avaamalla tai sulkemalla. Vuosina 1964-1965 haluttaessa $\mathrm{CO}_{2}$-pitoisuuden pysyvän pienempänä kuin $1 \%$ :na, hiilidioksidipitoisuuden säätö tapahtui absorptiopatsaan (NaOH-liuos) avulla.

Varastoinnin aikana säännöllisin väliajoin määritettiin kaapeissa olevan ilman hiilidioksidipitoisuus Riken-Keiki-kaasuindikaattorilla. Kaappien ilman happipitoisuutta ei tutkimusten aikana mitattu, mutta kirjallisuustietojen perusteella sen laskettiin olevan likimäärin $21-\mathrm{CO}_{2} \%$ (KUPRIANOFF 1960). Näin ei $\mathrm{O}_{2}$-pitoisuutta kuitenkaan voida laskea niistä kokeista, joissa käytettiin $\mathrm{NaOH}$-liuosta hiilidioksidipitoisuuden säätelyyn.

Kokeiden aikana ei kaappeja avattu, koska tällöin ilman koostumus olisi hetkessä muuttunut. Siksi ei säilytyksen aikana myöskään tarkastettu kasvien kuntoa, vaan säilyvyydestä tehtiin havainnot vasta kokeen loputtua, jolloin tuotteet punnittiin, kunnostettiin ja arvosteltiin. Punnitustulokset ilmaistaan prosentteina tutkittavan erän alkuperäisestä kunnostetusta painosta ja kaasuvarastoinnin tuloksia verrataan samanaikaisesti suoritetun kylmävarastoinnin $\left(1-2^{\circ}, 90-95 \%\right.$ suht. kost.) tuloksiin (vrt. VoIPIo 1966).

\section{Kokeiden selostus ja tulokset}

Alustavissa salaatin (lajike Herttaässä) kaasuvarastointikokeissa v. 1963 - 64 selvitettiin, onko mahdollista varastoida salaattia umpinaisessa tilassa ja minkälaiseksi varastointitappiot muodostuvat verrattuna kylmävarastoinnin tappioihin. V. 1963 kaasuvarastointiaika oli varsin pitkä, 40 vrk, ja kaasuvaraston ilman $\mathrm{CO}_{2}$-pitoisuus $0.04-2 \%$. Tällöin kokonaistappio oli $80 \%$. Seuraavana vuonna kaasuvarastointiaika oli enintään kolme viikkoa. Vertailtaessa kokeiden loputtua kaasuvarastoinnin ja kylmävarastoinnin tappioita toisiinsa (taulukko 1) havaittiin, että haihtumis- ja kokonaistappiot olivat edellisessä varastointitavassa pienemmät kuin jälkimmäisessä. Viikon pituisena aikana kaasuvarastossa salaattierät menettivät haihdunnan takia $4-5 \%$ painostaan. Kunnostusta nämä salaatit eivät tarvinneet. Kaksi viikkoa kaasuvarastossa olleiden erien kokonaistappio oli $14-15 \%$. Kun kaasuvarastointia jatkettiin kolme viikkoa, olivat koejäsenten kokonaistappiot toisistaan poikkeavat. Pienin kokonaistappio $26 \%$ mitattiin erässä, jonka alkuperäinen paino oli $8 \mathrm{~kg}$ ja jonka varastoinnin aikana ilman $\mathrm{CO}_{2}$-pitoisuus nousi $5 \%$ :iin. $39 \%$ :n kokonaistappio todettiin alkujaan $4 \mathrm{~kg}$ :n suuruisessa salaattierässä, jonka varastoilman $\mathrm{CO}_{2}$-pitoisuus pidettiin absorptiopatsaan avulla $0.5 \%$ :na, ja $44 \%$ :n kokonaistappio samansuurui- 
Taulukko 1. Salaatin (Herttaässä) varastointi v. 1964.

Table 1. Storage of lettuce (Passe Partout) in 1964.

\begin{tabular}{|c|c|c|c|c|}
\hline $\begin{array}{l}\text { Varastointitapa } \\
\text { Storage method }\end{array}$ & $\begin{array}{c}\text { Erän alku- } \\
\text { peräinen paino }\end{array}$ & $\begin{array}{l}\text { Varastointi- } \\
\text { aika }\end{array}$ & $\mathrm{CO}_{2} \%$ & $\begin{array}{l}\text { Tappiot Storage losses \% } \\
\text { Haihdunta Kokonais }\end{array}$ \\
\hline & $\begin{array}{l}\text { Weight of } \\
\text { stored lot } \mathrm{kg}\end{array}$ & $\begin{array}{l}\text { Storage period } \\
\text { vrk days }\end{array}$ & & Evaporation \\
\hline
\end{tabular}

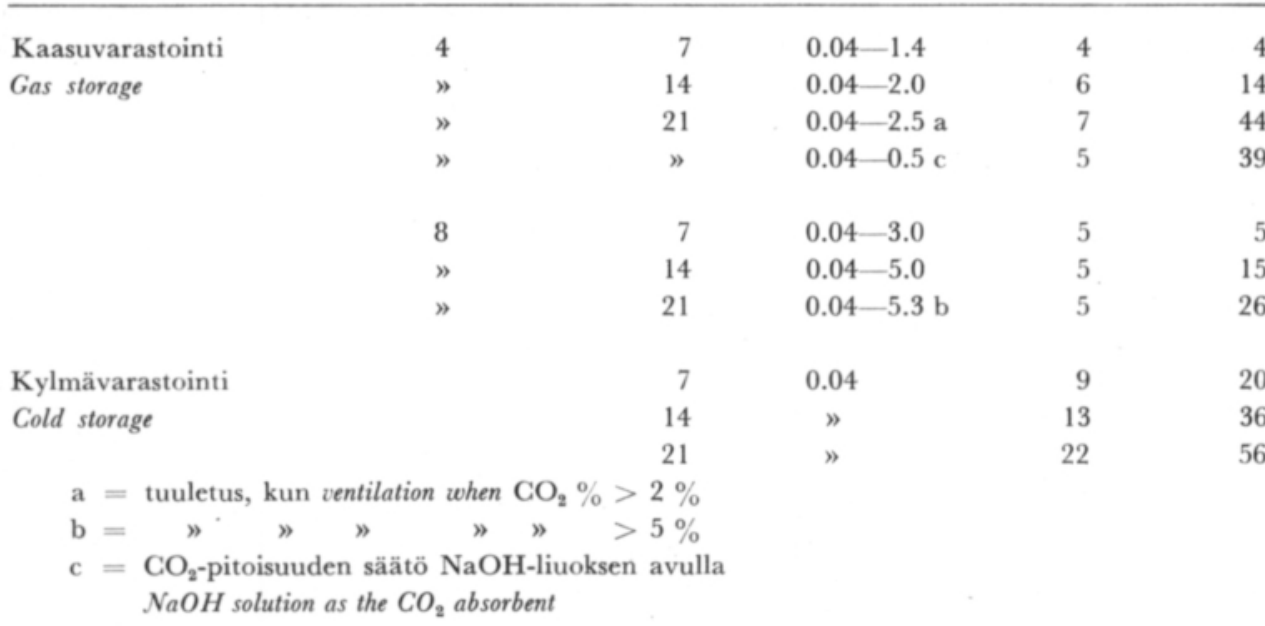

sessa koejäsenessä, jonka varastoinnin aikana ilman $\mathrm{CO}_{2}$-pitoisuus oli $0.04-2.5 \%$. Haihtumistappioissa sen sijaan oli vain vähäisiä eroavuuksia. Ilman $\mathrm{CO}_{2}$-pitoisuuksia mitattaessa havaittiin, että $\mathrm{CO}_{2}$-pitoisuuden lisääntyminen oli lähes kaksi kertaa nopeampaa $8 \mathrm{~kg}$ salaattia sisältäneissä kaapeissa kuin $4 \mathrm{~kg}$ sisältäneissä.

Jatkettaessa salaatin kaasuvarastointikokeita v. 1965 selvitettiin edelleen salaattimäärän vaikutusta ilman $\mathrm{CO}_{2}$-pitoisuuteen, varastoinnin pituuden (2 tai 4 viikkoa) vaikutusta tappioihin ja sitä, kuinka salaatti säilyy kaasuvarastossa, jonka ilman $\mathrm{CO}_{2}$-pitoisuus absorptiopatsaan avulla pidetään pienempänä kuin $0.5 \%$ na (Herttaässä, erät $\mathrm{D}_{1}$ ja $\mathrm{D}_{2}$, kuva 1 ). Toisena tutkittavana lajikkeena Herttaässän ohessa oli Great Lakes. Tulokset kokeista esitetään kuvassa 1 , jossa esitetyistä $\mathrm{CO}_{2} \%$-käyristä nähdään, että varastointijakson ensimmäisinä vuorokausina kaappien ilman $\mathrm{CO}_{2}$-pitoisuus nousi nopeimmin, mikä oli todettavissa myös edellisen vuoden mittaustuloksista. Tämän jälkeen $\mathrm{CO}_{2}$-pitoisuus nousi miltei suoraviivaisesti, kunnes tuuletus (Great Lakes erä $\mathrm{A}_{2}$ ja Herttaässä erä $\mathrm{A}_{2}$ ) aloitettiin. Nousunopeus oli riippuvainen kaapissa olevasta salaattimäärästä ja -lajikkeesta. Great Lakes -salaattia sisältäneissä kaapeissa ilman $\mathrm{CO}_{2}$-pitoisuus nousi hitaammin kilomäärää kohti kuin Herttaässää sisältäneissä kaapeissa, mikä ilmenee seuraavista 14. varastointivuorokauden aikana saaduista mittaustuloksista.

Herttaässä

\begin{tabular}{|c|c|}
\hline $3.2 \mathrm{~kg}$ & 1.45 \\
\hline $3.2 \mathrm{n}$ & 1.55 \\
\hline $5.3 n$ & 2.55 \\
\hline $6.6 ”$ & 2.80 \\
\hline $9.1 \mathrm{n}$ & 4.50 \\
\hline $9.6 ”$ & 5.00 \\
\hline
\end{tabular}

\section{Great Lakes}

$\begin{array}{rlll}5.9 \mathrm{~kg} & & 1.95 \% & \mathrm{CO}_{2} \\ 6.5 ” & 1.90 \% \\ 12.7 ” & 3.20 \% \\ 13.4 ” & 3.65 \%\end{array}$


Kahden viikon pituisen kaasuvarastointijakson päätyttyä v. 1965 oli Herttaässä-salaatin haihtumistappio 6-9\% ja kokonaistappio 10-15\%, Great Lakes -salaatin $2 \%$ ja $7 \%$ (kuva 1). Samaa lajiketta käsittävien koejäsenten välillä ei säilyvyydessä mainittavia eroja ollut. Neljä viikkoa jatkuneen kaasuvarastoinnin jälkeen oli Herttaässä-erien haihtumistappio 8-12\%, mutta kokonaistappioissa oli huomattavia eroja. Heikoimmin (kokonaistappio $49 \%$ ) säilyi erä $\mathrm{D}_{2}$, jonka alkuperäinen paino oli $3.3 \mathrm{~kg}$ ja jonka varastoinnin aikana $\mathrm{CO}_{2}$-pitoisuus oli n. $0.1 \%$. Vastaavansuuruisen erän $\mathrm{A}_{2}$, jota varastoitiin $0.04-2 \%: \mathrm{n}$ $\mathrm{CO}_{2}$-pitoisuudessa, kokonaistappio oli $35 \%$. Pienin kokonaistappio $(20 \%)$ todettiin erässä
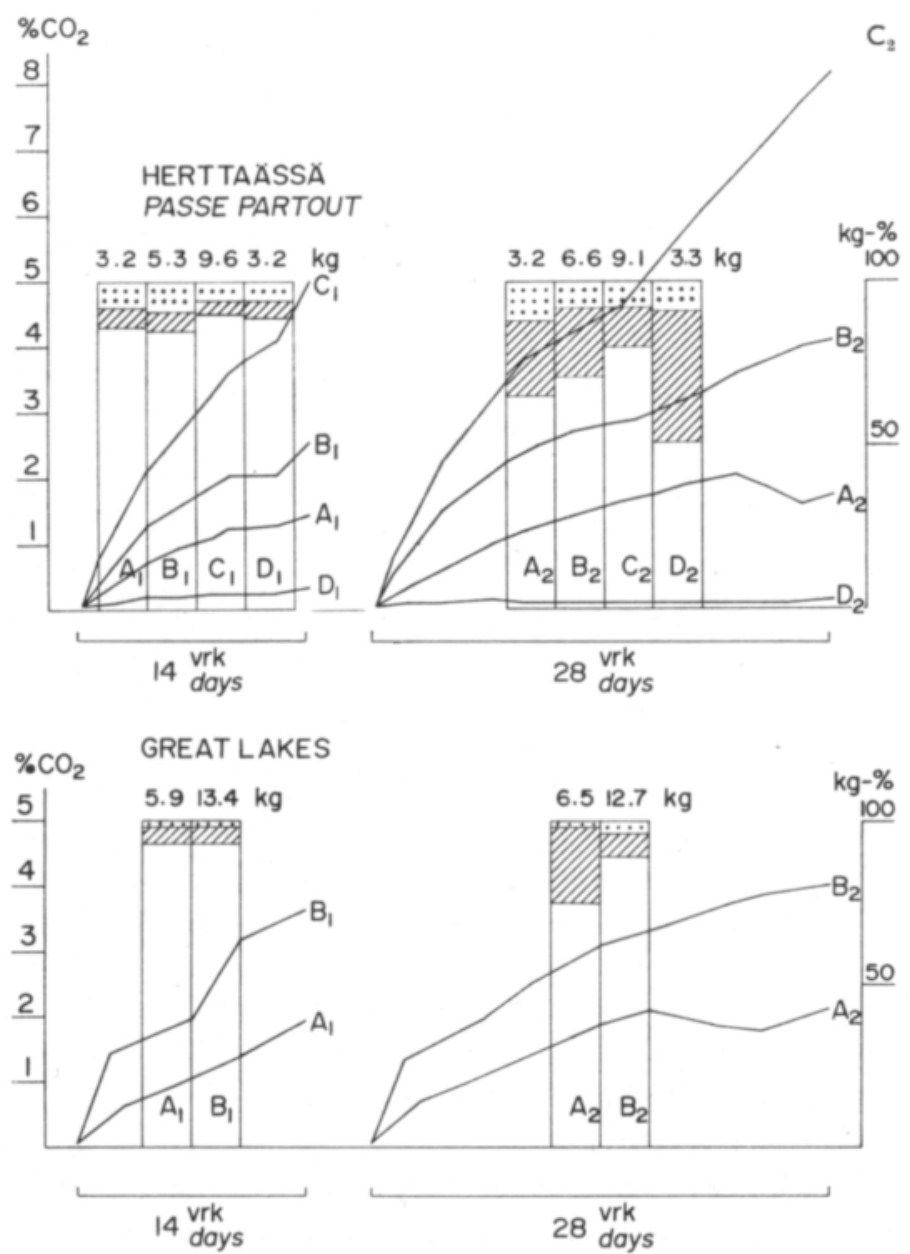

Kuva 1. Salaatin (Herttaässä ja Great Lakes) kaasuvarastoinnin aikana vallinneet ilman $\mathrm{CO}_{2}$-pitoisuudet $(\%)$, erien alkuperäiset painot $(\mathrm{kg})$ ja varastointitappiot $(\%) \mathrm{v} .1965$.'

Figure 1. Gas storage of lettuce (Passe Partout and Great Lakes) in 1965, the CO $\mathrm{C}_{2}$-concentrations of air (\%) during storage, the original weights $(\mathrm{kg})$ of different lots and the storage losses $(\%)$.

$\overline{|::::::|}=\begin{gathered}\text { haihtumistappio } \\ \text { losses by evaporation }\end{gathered}$

$\underline{\|/\|}=\underset{\text { kunnostustappio }}{\text { trimming losses }}$ 
$\mathrm{C}_{2}$, jonka alkuperäinen paino oli $9.1 \mathrm{~kg}$ ja jonka varastoinnin aikana ilman $\mathrm{CO}_{2}$-pitoisuus nousi $8 \%$ :iin. Great Lakes -salaatin kokonaistappiot 4 viikkoa jatkuneen varastoinnin päätyttyä olivat $35 \%\left(6.5 \mathrm{~kg}, 0.04-2 \% \mathrm{CO}_{2}\right)$ ja $11 \%\left(12.7 \mathrm{~kg}, 0.04-4 \% \mathrm{CO}_{2}\right)$ (kuva 1).

Vuonna 1966 toistettiin koe kaasuvarastoinnin pituuden vaikutuksesta tappioiden suuruuteen ja kilomäärään vaikutuksesta ilman $\mathrm{CO}_{2}$-pitoisuuteen. Tulokset tästä kokeesta esitetään taulukossa 2(koe I), josta käy ilmi, että kaasuvarastossa tappiot olivat pienemmät kuin kylmävarastossa. Herttaässän kohdalla kuitenkin säilyvyyden lisääntyminen oli selvempää kuin Great Lakes -lajikkeen kohdalla. Kaasuvarastossa olleen Herttaässän kokonaistappio oli puolta pienempi kuin kylmävarastossa säilytetyn, mutta Great Lakes -lajikkeen kohdalla ero oli vain $2-3 \%$. Hiilidioksidimäärän kehitystä tutkittaessa havaittiin sama suuntaus kuin edellisinä vuosina.

Taulukko 2. Salaatin (Herttaässä $=\mathrm{H}$, Great Lakes = G) varastointi v. 1966.

Table 2. Storage of lettuce (Passe Partout $=H$, Great Lakes $=G$ ) in 1966

\begin{tabular}{|c|c|c|c|c|c|c|c|c|c|}
\hline \multirow[b]{2}{*}{$\begin{array}{l}\text { Varastointitapa } \\
\text { Storage method }\end{array}$} & \multirow{2}{*}{\multicolumn{2}{|c|}{$\begin{array}{l}\text { Lajike } \\
\text { Variety }\end{array}$}} & \multirow[b]{2}{*}{$\begin{array}{c}\text { Erän alku } \\
\text { peräinen } \\
\text { paino kg } \\
\text { Weight of } \\
\text { stored lot } k_{\mathrm{g}}\end{array}$} & \multicolumn{6}{|c|}{$\begin{array}{c}\text { V a r a s o in tiaika Lengthof storage } \\
14 \text { vrk days } \\
28 \text { vrk days }\end{array}$} \\
\hline & & & & $\begin{array}{l}\mathrm{CO}_{2} \% \\
\mathrm{f} \\
\mathrm{fg}\end{array}$ & $\begin{array}{c}\text { Haih- } \\
\text { dunta \% } \\
\text { Evapo- } \\
\text { ration } \%\end{array}$ & $\begin{array}{c}\text { Kokonais- } \\
\text { tappio \% } \\
\text { Total } \\
\text { losses } \%\end{array}$ & $-\mathrm{CO}_{2} \%$ & $\begin{array}{c}\text { Haih- } \\
\text { dunta } \% \\
\text { Evapo- } \\
\text { ration } \%\end{array}$ & $\begin{array}{c}\text { Kokonais- } \\
\text { tappio } \% \\
\text { Total } \\
\text { losses } \%\end{array}$ \\
\hline Kaasuvarastointi, koe & I & $\mathbf{H}$ & 3.5 & $0.04-1.8$ & 10 & 18 & $0.04-2.2 \mathrm{a}$ & 9 & 24 \\
\hline Gas storage, test & I & $"$ & 6.5 & $0.04-4.0$ & 7 & 15 & $0.04-5.2 \mathrm{~b}$ & 9 & 22 \\
\hline & & G & $"$ & $0.04-2.2$ & 4 & 15 & $0.04-4.8$ & 5 & 21 \\
\hline & & $\mathrm{H}$ & 12 & $0.04-6.2$ & 5 & 11 & $0.04-9.2$ & 6 & 19 \\
\hline Kaasuvarastointi, koe I & II & $\mathbf{H}$ & 15 & $0.04-8.0$ & 4 & 9 & $0.04-10.2$ & 5 & 20 \\
\hline Gas storage, test & II & $"$ & $n$ & $0.04-7.6$ & 5 & 9 & $0.04-9.2$ & 7 & 25 \\
\hline & & G & 23 & $0.04-7.2$ & 3 & 11 & $0.04-15.2$ & 3 & 88 \\
\hline & & $"$ & $"$ & & & & $0.04-15.4$ & 4 & 86 \\
\hline Kylmävarastointi & & $\mathbf{H}$ & & 0.04 & 20 & 38 & 0.04 & 28 & 50 \\
\hline Cold storage & & G & & 0.04 & 7 & 18 & 0.04 & 10 & 23 \\
\hline
\end{tabular}

$\mathrm{a}=$ tuuletus, kun ventilation when $\mathrm{CO}_{2} \%>2 \%$

b $=" \quad " \quad$ " $\quad$ " $>5 \%$

Edellä esitetyn kokeen rinnalla suoritettiin v. 1966 myös toinen koe, jossa pyrittiin selvittämään, kuinka korkealle kaappien ilman $\mathrm{CO}_{2}$-pitoisuus nousee, jos niihin pannaan niin paljon salaattia, kuin sitä turmelematta on mahdollista, ja aiheutuuko korkeasta $\mathrm{CO}_{2}$-pitoisuudesta vaurioita. Herttaässä-salaattia mahtui kaappiin $15 \mathrm{~kg}$ ja Great Lakes -salaattia $23 \mathrm{~kg}$. Varastointiaika tässä kokeessa oli 2 tai 4 viikkoa, ja kokeen tulokset esitetään taulukossa 2 (koe II).

Kun kaasuvarastointia kokeessa II oli jatkunut 2 viikkoa, oli Herttaässää sisältäneissä kaapeissa $\mathrm{CO}_{2}$-pitoisuus noussut 7.6-8\%:iin ja Great Lakesia sisältäneessä $7.2 \%$ :iin. Näiden erien kokonaistappio oli 9-11\%. Neljän viikon kuluessa nousi $\mathrm{CO}_{2}$-pitoisuus Herttaässää sisältäneissä kaapeissa 9.2-10.2\%:iin ja Great Lakesia sisältäneissä 15.2 - 
Taulukko 3. Salaatin (Herttaässä) varastointi v. 1968.

Table 3. Storage of lettuce (Passe Partout) in 1968.

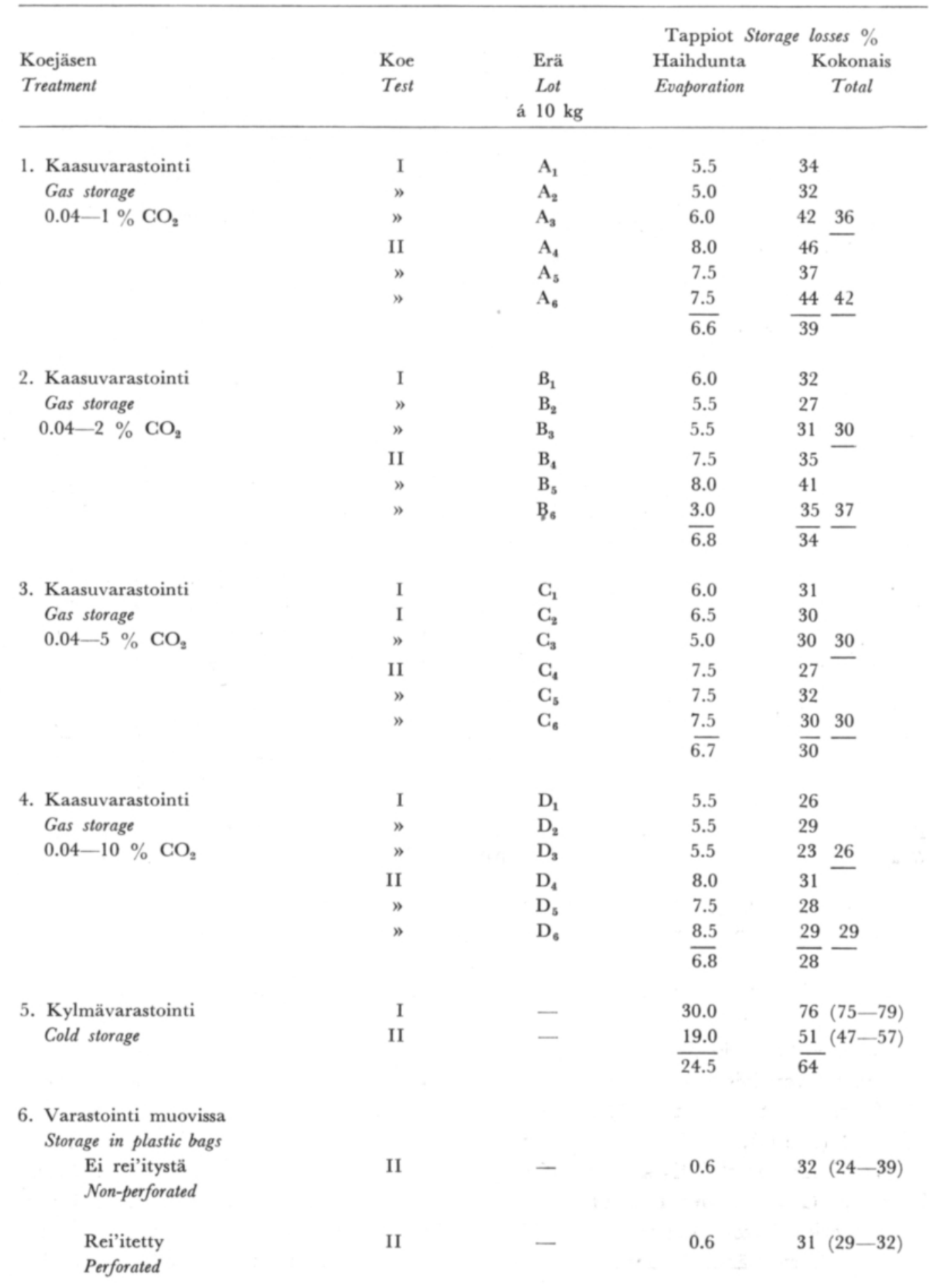


$15.4 \%$ :iin. Herttaässän kokonaistappio oli 20-25\%. Great Lakes -salaatin kokonaistappio oli suuri, $86-88 \%$, mikä johtui siitä, että miltei kaikki kerät olivat sisäosistaan vioittuneita.

Koska v. 1964 - 66 suoritetuissa Herttaässä-salaatin kaasuvarastointikokeissa ilmeni käänteinen suhde kokonaistappion ja $\mathrm{CO}_{2}$-pitoisuuden välillä, suoritettiin v. 19682 tarkistuskoetta erilaisten $\mathrm{CO}_{2}$-pitoisuuksien vaikutuksesta tappioihin. Näissä kokeissa kuhunkin kaappiin varastoitiin $10 \mathrm{~kg}$ salaattia ja kaappien ilman $\mathrm{CO}_{2}$-pitoisuudet säädettiin tuuletuksen avulla eri tavoitetasoille: $0.04-1 \%, 0.04-2 \%, 0.04-5 \%$ ja $0.04-10 \%$. Lisäksi selvitettiin rinnakkaiserien avulla hajonnan suuruutta ja sen syitä.

Molempia kokeita varten viljeltiin salaattierät, joista ensimmäinen vietiin varastoon 22.-23. 7. (kerien lämpötila korjattaessa $11-14^{\circ}$ ) ja toinen 23. 8. (kerien lämpötila korjattaessa $\left.23-26^{\circ}\right)$. Kaasuvarastointikokeitten ohessa suoritettiin kokeet kylmävarastossa. Tuloksista (taulukko 3) varmentui käsitys, jonka mukaan Herttaässän kokonaistappio on sitä pienempi, mitä korkeampi on $\mathrm{CO}_{2}$-pitoisuus. Niinpä $0.04-1 \%$ :n $\mathrm{CO}_{2}$-pitoisuutta vastaava keskimääräinen kokonaistappio oli $39 \%, 0.04-2 \%$ a vastaava $34 \%, 0.04$ $5 \%$ :a vastaava $30 \%$ ja $0.04-10 \%$ : $\mathrm{CO}_{2}$-pitoisuutta vastaava kokonaistappio $28 \%$. Keskimääräinen haihtumistappio sen sijaan näytti olevan riippumaton vallitsevasta $\mathrm{CO}_{2}$ pitoisuudesta. Vertailtaessa kokeen I ja kokeen II keskimääräisiä kokonaistappioita todettiin, että kokeessa I kaasuvarastoinnin tappiot olivat pienemmät, $31 \%$, kuin kokeessa II, $35 \%$. Kylmävarastoinnin kokonaistappiot asettuivat suuruudeltaan päinvastaiseen järjestykseen: koe I $76 \%$ ja koe II $51 \%$.

Rinnakkaiserien hajonta oli suurinta koejäsenessä 1 , jonka varastoinnin aikana $\mathrm{CO}_{2^{-}}$ pitoisuus oli $0.04-1 \%$. Kokeessa I suurimman ja pienimmän kokonaistappion erotus oli $10 \%$ ja kokeessa II $9 \%$. Muiden rinnakkaiserien suurimman ja pienimmän kokonaistappion erotus vaihteli välillä $1-6 \%$. Varastoinnin aikana vallinneita $\mathrm{CO}_{2}$-pitoisuuksia tarkasteltaessa (kuva 2) voitiin havaita, että koejäsenessä 1. oli suhteellisesti suurimmat erot ilman $\mathrm{CO}_{2}$-pitoisuuksissa ja että jo $0.1 \%$ :n ero keskimääräisessä $\mathrm{CO}_{2}$-pitoisuudessa näytti aiheuttavan säilyvyyseroja, kuten seuraavasta asetelmasta nähdään.

$$
\text { Keskim. } \mathrm{CO}_{2} \% \quad \text { Kok.tappio } \%
$$

$\begin{array}{ccc}\text { Koe I } & 0.49 & 42 \\ & 0.61 & 32 \\ & 0.66 & 34 \\ \text { Koe II } & & \\ & 0.53 & 44 \\ & 0.57 & 46 \\ & 0.67 & 37\end{array}$

Ilman $\mathrm{CO}_{2}$-pitoisuuksia mitattaessa taas ilmeni, että kokeessa I hiilidioksidia kehittyi nopeammin kuin kokeessa II (kuva 2). Esimerkiksi $5 \%$ :n raja saavutettiin kokeessa I n. 6 vrk:n ja kokeessa II n. 10 vrk:n kuluttua kokeen aloituksesta. Lisäksi havaittiin, että niissä kaapeissa, joissa $\mathrm{CO}_{2}$-pitoisuuden haluttiin nousevan $10 \%$ :iin, $\mathrm{CO}_{2} \%$ :n kasvu pysähtyi parin päivän ajaksi silloin, kun $\mathrm{CO}_{2}$-pitoisuus oli n. $5 \%$. Kokeessa I tämä vaihe esiintyi 6-8 vrk:n kuluttua kokeen aloituksesta ja kokeessa II 12-14 vrk:n kuluttua.

Kaasuvarastointikokeitten rinnalla suoritettiin kylmävarastossa v. 1968 kokeen II 

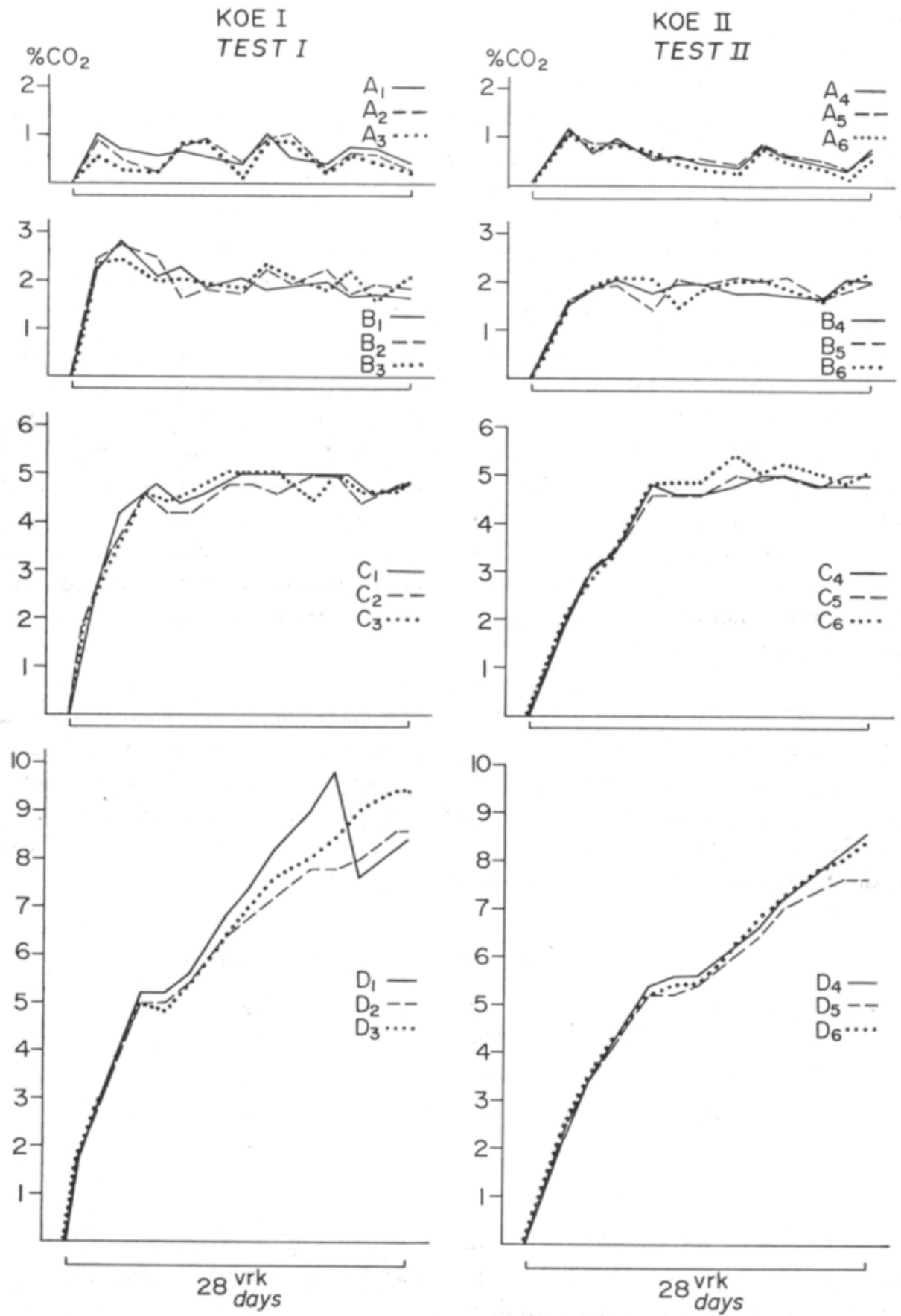

Kưva 2. Salaatin (Herttaässä) kaasuvarastoinnin aikana vallinneet ilman CO'-pitóisuudet (\%) kokeessa I ja II vuonna 1968.

Figure 2. The $\mathrm{CO}_{2}$-concentrations of air (\%) during gas storage of lettuce (Passe Partout) in tests I and II in 1968. 
yhteydessä myös koe rei'ittämättömään tai rei'itettyyn muoviin pakatun salaatin säilyvyydestä. Muoviin pakatun salaatin kokonaistappio neliviikkoisen varastoinnin päätyttyä (taulukko 3 ) oli $31-32 \%$ ja haihtumistappio $0.6 \%$.

Vuosina 1966 ja 1968 tehtiin myös havaintoja lehdenreunapoltteen esiintymisestä Herttaässä-salaatissa satoa korjattaessa ja varastoinnin päätyttyä. V. 1966 satoa korjattaessa todettiin silminhavaittavasti poltteen vioittamaksi 10 kerää 100:sta, mutta v. 1968 kerät olivat terveitä. Neljä viikkoa jatkuneen varastoinnin päätyttyä tavattiin poltteen vioittamia keriä seuraavasti.

\begin{tabular}{|c|c|c|c|c|c|c|c|}
\hline Kaasuvarastointi & v. 1966 & & & tautisia & 25 & kerää & 100 :sta \\
\hline$»$ & v. 1968 & koe & I & $»$ & 9 & " & $»$ \\
\hline$"$ & $"$ & koe & II & $»$ & 10 & $"$ & " \\
\hline Kylmävarastointi & v. 1966 & & & $"$ & 56 & ” & " \\
\hline " & v. 1968 & koe & I & " & 32 & ” & " \\
\hline$"$ & " & koe & II & $"$ & 10 & $"$ & " \\
\hline
\end{tabular}

Varastoinnin aikana siis poltteen vioittamien kerien määrä lisääntyi, kaasuvarastossa kuitenkin vähemmän kuin kylmävarastossa.

\section{Tulosten tarkastelu}

Aloitettaessa salaatin kaasuvarastointitutkimukset esiintyi epätietoisuutta siitä, voidaanko salaattia lainkaan varastoida umpinaisessa tilassa. Tarjolla oli mahdollisuus, että salaatti kehittämiensä eritteiden, esim. hiilidioksidin (BROoks et al. 1936) tai etyleenin (Roop 1956), vaikutuksesta vioittuisi. Alustavat tutkimukset kuitenkin osoittivat, ettei kaasuvarastossa kellastumista tai muuta muuttuneeseen ilman koostumukseen viittaavaa näkyvää vioitusta ollut. Sen sijaan heti kaasuvarastosta oton jälkeen salaatissa oli todettavissa tunkkautunut haju, joka kuitenkin pian haihtui. Salaatin maussa ei outoja piirteitä havaittu.

Alustavissa kokeissa kävi myös ilmi, että kaasuvarastossa tappiot muodostuivat pienemmiksi kuin kylmävarastossa. Jatkokokeissa tämä suuntaus vahvistui nimenomaan Herttaässä-lajikkeen kohdalla. Vuosina 1964 - 66 ja 1968 kaasuvarastossa Herttaässän kokonaistappio oli keskimäärin puolta pienempi kuin kylmävarastossa.

Haihdunta kaasuvarastossa oli vähäisempää kuin kylmävarastossa, sen määrä pieneni varastoidun salaattierän suuretessa, ja varastointiajan pidetessä haihdunnan määrä kasvoi vain vähän. Kaikki edellä mainitut seikat viittaavat siihen, että kaappien sulkemisen jälkeen salaatti luovutti vettä, kunnes kosteustasapaino saavutettiin. Koska kosteutta ei kaappien ilmasta sanottavasti poistunut (joskus kaappeja aukaistaessa havaittiin vettä tiivistyneen kaapin seinämiin), kuten kylmävarastossa oli laita, salaatista tapahtuva kokonaishaihdunta jäi pieneksi.

Korkean suhteellisen kosteuden lisäksi myös ilman koostumuksella oli vaikutusta kokonaistappion määrään. Kun kaasuvarastossa ilman $\mathrm{CO}_{2}$-pitoisuus oli $10 \%$ tai sitä pienempi, oli todettavissa käänteinen suhde hiilidioksidipitoisuuden ja kokonaistappioitten välillä. Vielä niin alhaisissa kuin alle $1 \%$ :n hiilidioksidipitoisuuksissa näytti pitoisuuseroilla 
olevan merkitystä. Edellä esitettyjen tutkimusten perusteella ei kuitenkaan voida, koska tutkimuksessa ei erikseen selvitetty happipitoisuuden alentamisen merkitystä, lopullisesti sanoa, missä määrin ilman $\mathrm{CO}_{2}$-pitoisuuden lisääntyminen ja $\mathrm{O}_{2}$-pitoisuuden aleneminen osaltaan vaikuttivat lopputulokseen.

Aikaisemmissa vihannesten kaasuvarastointitutkimuksissa on selvästi saatu viite siitä, että vasta happipitoisuuden ollessa hyvin alhainen päästään vihannesten värin muutosten ehkäisyssä samansuuntaiseen tulokseen kuin ilman lisätyn $\mathrm{CO}_{2}$-pitoisuuden avulla. Niinpä EAves ja LockHART (1961) totesivat tomaatin kaasuvarastointitutkimuksissa, että $\mathrm{CO}_{2}$ pitoisuuden nostaminen $5 \%$ :iin hidasti tomaatin kypsymistä ja että kypsymisen hidastuminen saatiin myös aikaan alentamalla ilman $\mathrm{O}_{2}$-pitoisuus $2.5 \%$ :iin. Apelandin (1961) tutkimuksissa taas kurkkujen kellastuminen hidastui, kun ilman $\mathrm{CO}_{2}$-pitoisuus kohosi 0:sta $5 \%$ :iin, mutta myös happipitoisuuden alentamisella $16 \%$ :sta $5 \%$ :iin oli kellastumista hidastava vaikutus. Lieberman ja Hardenburg (1954) puolestaan totesivat, että parsakaalin kellastuminen kaasuvarastossa oli yhtä nopeaa, kun $\mathrm{O}_{2}$-pitoisuus alennettiin $1 \%$ :iin tai kun ilman $\mathrm{CO}_{2}$-pitoisuus nousi $22 \%$ :iin $\mathrm{O}_{2}$-pitoisuuden samanaikaisesti ollessa 10 $21 \%$.

Värin muutosten ohella on kaasuvaraston ilman koostumuksella todettu olevan muitakin säilyvyyttä lisääviä vaikutuksia. Ilman $\mathrm{O}_{2}$-pitoisuuden alentuessa tiedetään hengityksen intensiteetin hidastuvan (esim. Lieberman \& Hardenburg l.c.), korkealla $\mathrm{CO}_{2}$ pitoisuudella on taas mikrobien toimintaa rajoittava vaikutus (esim. EAves \& LockHART 1961).

Salaatista erittyy Borgströmin (1957) mukaan 30-55 mg $\mathrm{CO}_{2}$ :a kiloa kohti tunnissa, mikä edellyttäisi kokeissa käytetyissä kaapeissa päivittäistä $0.1-0.2 \%$ :n suuruista $\mathrm{CO}_{2}$ pitoisuuden nousua salaattikiloa kohti. Tämän perusteella ei kaappien ilman $\mathrm{CO}_{2}$-pitoisuuden lisääntymistä varastoinnin pidetessä kuitenkaan voitu ennustaa. Jo kahden varastointivuorokauden jälkeen mittauksia suoritettaessa todettiin, että esim. Herttaässää sisältäneissä kaapeissa ilman $\mathrm{CO}_{2}$-pitoisuus oli lisääntynyt keskimäärin vain $0.08 \% / \mathrm{kg} / \mathrm{vrk}$. 14. varastointivuorokauden mittaustulosten perusteella laskettu keskimääräinen nousunopeus oli vielä pienempi, $0.04 \% / \mathrm{kg} / \mathrm{vrk}$. Varastointiajan pidetessä siis hiilidioksidin erittyminen vähenee.

Salaatin kaasuvarastointia suunniteltaessa ja asetettaessa tavoitteeksi erilaisia $\mathrm{CO}_{2}$-pitoisuuksia tulee edellisen lisäksi otettavaksi huomioon se, että happipitoisuuden aletessa hiilidioksidin erittyminen hidastuu. Tämä merkitsee edellä esitettyä kaasuvarastointimenetelmää käytettäessä sitä, että pientä kilomäärää vastaava $\mathrm{CO}_{2}$-pitoisuus muodostuu suhteellisesti suuremmaksi kuin suurta kilomäärää vastaava. Herttaässällä eri vuosina esim. 14 . varastointivuorokautena mitattujen $\mathrm{CO}_{2}$-pitoisuuksien (niistä kaapeista, joissa ei $\mathrm{CO}_{2}$-pitoisuuden säätöä mainittuun havaintopäivään mennessä suoritettu) ja alkuperäisten kilomäärien välinen suoraviivainen korrelaatio $\left(\mathrm{y}_{\mathrm{r}}=0.61+0.47 \mathrm{x}\right)$ kuitenkin viittaa siihen, että käytännössä voidaan happipitoisuuden alentumisesta aiheutuvan hiilidioksidin erittymisen hidastumisen ajatella tapahtuvan suoraviivaisesti ainakin silloin, kun $\mathrm{O}_{2}$-pitoisuus ei alita $10 \%$ :a. Tosin esim. v. 1968 todettiin $\mathrm{CO}_{2} \%$ :n kasvussa tauko, kun $\mathrm{CO}_{2}$-pitoisuus oli noussut $5 \%$ :iin. Tämä ilmiö voitaneen käsittää hengitysmekanismissa tapahtuvan muutoksen aiheuttamaksi.

Käytännön kannalta lienee kiintoisa myös se havainto, ettei neljän viikon aikana Herttaässä-salaatti täyteen ahdetussakaan kaapissa tai rei'ittämättömässä muovipussissa muut- 
tanut ilman koostumusta niin paljoa, että siitä olisi ollut vahingollisia seurauksia. Great Lakes -lajikkeesta saadut kokemukset osoittavat kuitenkin, että lajikohtaiset tutkimukset ovat välttämättömät ja että yli $10 \%$ :n $\mathrm{CO}_{2}$-pitoisuus saattaa olla vahingollinen.

Hiilidioksidin kehittymisnopeuden suhteen havaittiin eroavuuksia, paitsi lajikkeiden välisiä myös saman lajikkeen, Herttaässän, kohdalla vuonna 1968. Varastoitaessa olivat salaattierät kehitysasteeltaan samat, sen sijaan II-erä oli rapeampaa ja sen korjuulämpötila oli korkeampi kuin I-erän. Näiden eroavuuksien johdosta odotettiin II-erän kehittävän hiilidioksidia nopeammin kuin I-erän. Kuitenkin II-erää sisältäneissä kaapeissa $\mathrm{CO}_{2}$-pitoisuus nousi hitaammin kuin I-erää sisältäneissä. Selityksenä saattaa olla se, että jo 23$26^{\circ}$ :n lämpötilassa, joka oli II-erän kerien lämpötila korjattaessa, salaatin ilmaraot ovat osittain sulkeutuneet, mistä johtuisi hidastuminen hiilidioksidin erittymisessä. Se, että kylmävarastossa II-erästä tapahtuva haihdunta oli huomattavasti pienempää kuin I-erästä, tukee käsitystä ilmarakojen sulkeutuneisuudesta. II-erän haihdunta kaasuvarastossa oli suurempaa kuin I-erän, mikä taas selittynee rakenteellisista eroavuuksista.

\section{Tiivistelmä}

Salaatin kaasuvarastointia tutkittiin Viikissä vuosina 1963 - 66 ja 1968. Tutkittavina lajikkeina olivat avomaalla viljellyt Herttaässä ja Great Lakes. Varastoinnissa käytettiin menetelmää, jossa ilman koostumusta säädellään kasvinosien hengityksen ja tuuletuksen avulla. Tutkimuksessa selvitettiin tappioitten suuruutta, umpinaisessa tilassa tapahtuvaa ilman koostumuksen muuttumista ja $\mathrm{CO}_{2}$-pitoisuuden vaikutusta säilyvyyteen.

Kaasuvarastossa salaatin haihtumistappio oli pieni, alle $10 \%$ neljä viikkoa jatkuneessa säilytyksessä. Kylmävarastossa haihdunta saattoi samanpituisena aikana nousta $30 \%$ :iin. Herttaässä-salaatin kokonaistappio kaasuvarastossa oli keskimäärin puolta pienempi kuin kylmävarastossa. Great Lakes -salaatilla ei näin suuria eroja havaittu.

Kaasuvaraston ilman $\mathrm{CO}_{2}$-pitoisuuden lisääntyessä Herttaässän kokonaistappio pieneni. Great Lakes sen sijaan saattoi muuttaa ilman koostumusta niin paljon, että vioituksia aiheutui.

Kilomäärää kohti kehittyi Herttaässästä runsaammin hiilidioksidia kuin Great Lakesista. Varastointiajan pidetessä $\mathrm{CO}_{2}$-pitoisuuden nousu kaasuvarastossa hidastui, mikä johtui luontaisesta ja ilman muuttuneen koostumuksen aiheuttamasta hengityksen hidastumisesta.

\section{KIRJALLISUUTTA}

Anon. 1965 Refrigerated stores for fruit. Min. of Agric. Fish. and Food. Bull. No. 159. 29 p.

- - 1966 Transfresh: A sleeping service. Reprint from Western Grower \& Shipper. Yearbook 1966. 4 p.

APELAND, J. 1961. Factors affecting the keeping quality of cucumbers. Meld. nr. 15 fra Inst. for grønsakdyrking. Norges Landbrukhögskole. $14 \mathrm{~s}$.

Berg, L. VAn den \& Lenz, C. P. 1966. Effect of temperature, relative humidity, and atmospheric composition on changes in quality of carrots during storage. Food Technol. 20: 954 -957.

Borgström G. 1957. Hantering av grönsaker. 131 s. Göteborg.

Brooks, C., Bratley, C. O. \& Mc Colloch, L. P. 1936. Transit and storage diseases of fruits and vegetables as affected by initial carbon dioxide treatments. U.S. Dept. of Agr. Tech. Bull. No. 519. 24 p.

EAKs, I. E. 1956. Effect of modified atmospheres on cucumbers at chilling and non-chilling temperatures. 
Proc. Amer. Soc. Hort. Sci. 67: 473-478.

Eaves, C. A. \& Lockhart, C. L. 1961. Storage of tomatoes in artificial atmospheres using the calcium hydroxide absorption method. J. of Hort. Sci. 36: 85-92.

Fidler, J. C. 1963. Refrigerated storage of fruits and vegetables in the U.K., the British Commonwealth, the U.S.A. and South Africa. Ditton Lab. Mem. No. 93. 23 p.

KIDD, F. 1964. Beginnings of gas storage. Copy of J. of Refrigeration. Vol. 7. No 1. 4 p.

- - \& \& West, C. 1932. Gas storage of tomatoes. Rep. Fd Invest. Bd, Lond., 209-211. Ref. Tomkins, R. G. 1963.

Kuprianoff, J. 1960. Die Zusatzverfahren. Handbuch der Kältetechnik. Band 10: 101-126. Berlin.

Lieberman, M. \& Hardenburg, R. E. 1954. Effect of modified atmospheres on respiration and yellowing of broccoli at 75 degrees F. Proc. Amer. Soc. Hort. Sci. 63: 409-414.

Lipton, W. J. 1965. Post-harvest responses of asparagus spears to high carbon dioxide and low oxygen atmospheres. Ibid. 86: 347-356.

Lougheed, E. C. \& Dewey, D. H. 1966. Factors affecting the tenderizing effect of modified atmospheres on asparagus spears during storage. Ibid. 89: $336-345$.

Lyons, J. \& RAPPAPORT, L. 1962. Effect of controlled atmospheres on storage quality of brussels sprouts. Ibid. 81 : $324-331$.

Rood, P. 1956. Relation of ethylene and post harvest temperature to brown spot of lettuce. Ibid. 68: 296303.

Toмкıns, R. G. 1959. The conditions for the gas storage of certain fruits and vegetables obtained by the use of a simple small-scale method. Ditton Lab. Mem. No. 4. 4 p.

$\longrightarrow$ - 1963. The effects of temperature, extent of evaporation and restriction of ventilation on the storage life of tomatoes. J. of Hort. Sci. 38: 335-347.

Vorpıo, I. 1966. Keräsalaatin varastointi. Summary: Storage of head lettuce. J. Sci. Agric. Soc. Finland. 38: $15-26$.

——— \& HÅrdh, J. E. 1967. Auch bei Gemüse ist Gaslagerung möglich. Gemüse 3: 67-68.

WEst, C. 1951. The history of refrigerated gas storage for horticultural produce. Proc. of the Eight Intern. Congr. of Refrigeration, London 1951. pp. 406- 409.

\title{
SUMMARY
}

\section{GAS STORAGE OF HEAD LETTUCE}

\author{
IRMA SUHONEN \\ Institute of Horticulture, University of Helsinki, Viik
}

Refrigerated gas storage of field grown lettuce was studied in 1963 - 66 and in 1968. The gas storage method was of a simple type; the carbon dioxide was produced by the respiring lettuces and the concentration of gas was controlled by the ventilation. In 1964-65 three tests were made using $\mathrm{NaOH}$ solution as the $\mathrm{CO}_{2}$-absorbent. The gas stores were made of zinc, and their capacity was 3361 . The bins were situated in a refrigerated store where the temperature was $1-2^{\circ}$ and the relative humidity $90-95 \%$. The carbon dioxide content of the bin air was determined with the Riken Keiki gas indicator.

The questions studied were: can lettuce be stored in a refrigerated gas store, how big are the gas storage losses, is there any difference between storage losses obtained in cold storage in above mentioned circumstances and in gas storage, is there any difference in the keeping quality of two varieties (Passe Partout and Great Lakes), and what is the influence of different $\mathrm{CO}_{2}$ levels on the wastage.

According to the results (Tables 1 to 3, and Figure 1), lettuce could be stored in gas bins. The wastage after gas storage was usually smaller than after cold storage. For example, the average gas storage wastage of Passe Partout was only one half of the cold storage wastage. In gas stores the losses were limited by restricted evaporation and by concentration of gases. In the tests the keeping quality of the variety Passe 
Partout increased with a higher $\mathrm{CO}_{2}$-content. The above $10 \% \mathrm{CO}_{2}$-concentrations were not studied with the Passe Partout lettuce, because even when the bins were packed full of Passe Partout ( $15 \mathrm{~kg} / \mathrm{bin})$, the $\mathrm{CO}_{2}$-content during the 4 weeks' storage did not exceed $10 \%$. On the other hand, when the bins were packed full of Great Lakes (23 kg/bin), the $\mathrm{CO}_{2}$-content of the air during the 4 weeks' storage rose to $15 \%$, and the lettuce was injured badly.

Measuring the gas concentrations of the air during the tests we noticed that during the first two to three days period the $\mathrm{CO}_{2}$-content rose most quickly. With a lengthening of the storage period, the accumulation of $\mathrm{CO}_{2}$ became slower. This was caused by a natural decrease in respiration, and by a reduction of the $\mathrm{O}_{2}$-concentration. Based on the original weight of stored lettuce, Passe Partout produced quicker $\mathrm{CO}_{2}$ than Great Lakes. Differences in the rates of $\mathrm{CO}_{2}$-accumulation were also noted between different lots of the same variety. In 1968 the difference (Figure 2), for example, seemed to depend on the harvesting temperature, which for test I was $11-14^{\circ} \mathrm{C}$ and for test II $23-26^{\circ} \mathrm{C}$. It was assumed that in the latter temperature the stomata of the lettuce are partly closed, and therefore the rate of the $\mathrm{CO}_{2}$ evolution is reduced. 